\title{
Food security in China at 2050: a global CGE exercise
}

\author{
Kakali Mukhopadhyay ${ }^{1,2,3^{*}}$, Paul J. Thomassin ${ }^{1}$ and Jingyuan Zhang ${ }^{1}$
}

\section{${ }^{*}$ Correspondence:}

kakali.mukhopadhyay@

mcgill.ca

${ }^{2}$ Gokhale Institute

of Politics and Economics,

Pune 411004, India

Full list of author information

is available at the end of the article

\begin{abstract}
Since 2010, China has changed its position in the world grain market from a net exporter to a net importer. The total grain trade deficit was $\$ 420$ million in 2010. However, the increasing grain import contradicts its food security policy of achieving a $95 \%$ grain self-sufficiency rate. Additionally, Chinese agricultural productivity is lower than the world average, and much lower than high-income countries, which puts grave pressure on the country's food security target. Toward this end, the study investigates China's food security status in 2030 and the impact of alternative policies on food security. A global CGE framework (GTAP) has been used to estimate the impact of agriculture and trade policy interventions on food security in China. A recursive process is used to project the model to 2050 under business as usual. The study has attempted various scenarios to study the impact of food security in China. The results from this study suggest that China is expected to achieve a grain self-sufficiency level of a little above $90 \%$ by the year 2030 . The meat tariff reduction has a greater positive impact on China's food security than the other scenarios. In addition, most of the policies are beneficial for national welfare. The total value of agricultural imports and exports are expected to increase substantially. In addition, the current Red Line arable land protection policy (1800 million $\mathrm{mu}$ ) is determined to be insufficient to allow for the production of enough grain by 2030 to meet the desired $95 \%$ self-sufficiency rate. Study results indicate that arable land should be strictly protected for food production against pressure from industrialization and urbanization. However, it is only part of the food security solution and, policy interventions are required to ensure that China's food security targets are met.
\end{abstract}

Keywords: China, Food security, GTAP, Self-sufficiency

\section{Introduction}

The world faces multiple challenges in strengthening food security that ranges from rapid transition of diet consumption patterns of a continuously increasing population to constantly decreasing cultivated land and inefficient production practices (Beddington et al. 2012). The world population has increased from 6.4 billion in 2004 to 7.4 billion in 2016, and it is expected to reach 9.4 billion by 2050 (World Bank 2014a, 2016). In addition, the global average food consumption has increased from 2250 calories per capita per day in 1961 to 2750 calories per capita per day in 2007. This figure is projected to rise to 3070 calories per person per day by 2050 (Alexandratos and Bruinsma 2012). However, 870 million out of 7.04 billion people still experience transitory hunger. Moreover, 
over 98\% of these hungry people live in developing countries (FAO 2009; WFP and IFAD 2012). Therefore, food insecurity is still a serious global issue.

Strengthening food security is a focus for many countries, and it is a significant development strategy for the People's Republic of China. Food security in China can promote economic development, maintain social stability, and achieve national self-sufficiency (Zhou 2010). For the last two decades, China's food security has attracted great attention due to its growing population, improving purchasing power and soaring demand for animal feed and biofuel. On the other hand, agricultural production is a critical component of China's economy and peoples lives. Additionally, agricultural development continues to lag behind industrial development. It poses a significant challenge because China's agricultural production provides 1.3 billion people with food, 737 million rural people's incomes depend on agricultural production and $42.6 \%$ of the labor force is employed in agricultural sector. However, agricultural production only accounts for $10 \%$ of GDP even though 35.4 billion dollars of exports herald from the agricultural sector and $66 \%$ of the light industry outputs are based on agricultural products (China 2008; National Bureau of Statistics of China 2010; World Bank 2014b).

China's population has increased over 30\% since 1980 and is predicted to reach 1.3406 billion by 2050 (World Bank 2013). At present, China's total GDP ranks second in the world, and its annual GDP growth rate is approximately 8.6\% (World Bank 2014b). An upward trend in income has tripled food demand in the past 30 years (Liao 2010), and more arable land is made uncultivable as a result of rapid urbanization and industrialization. The per capita land resources in China are only equivalent to $0.38 \%$ of the world average (World Bank 2014c). Limited arable land has attracted more attention by government. The grain sufficiency rate of China is in danger of becoming lower than the target rate of $95 \%$ self-sufficiency, which is considered a key national food security indicator from the Chinese government's perspective. To feed approximately $22 \%$ of the world's population on less than $9 \%$ of the world's cropland is a major challenge. As a result, food security is a fundamental issue for policy makers and requires immediate attention.

\subsection{Limited arable land resources}

Several major factors have caused cultivable land to shrink in China, such as converting agricultural land to residential or industrial areas. At present, only $12.8 \%$ of the total national land area is available for agricultural production (Chen 2007). In addition, China's increased agricultural harvest in the past years to some extent can be attributed to the overuse of fertilizer and pesticide (Huang et al. 2012a). This is not a sustainable approach for a country that aims to maintain a stable grain supply in the long term. It is crucial to limit the loss of arable land to ensure food security. In response, the Chinese government has unveiled a series of new regulations and standards to safeguard sufficient arable land. Government has set, what it calls, a Red Line to guarantee that the amount of arable land never goes below 120 million hectares (1800 million $\mathrm{mu}$ ). However, whether this red line is enough for the population in 2030 and 2050 remains a concern.

\subsection{Agricultural trade}

Since 2010, China has changed its position in the world grain market from net exporter to net importer. The total grain trade deficit has increased significantly to $\$ 4$ billion in 
2013. Since joining the WTO, China has undertaken a series of tariff reductions policy mostly towards agricultural products. Major grain products, i.e., rice and wheat, are in the tariff reduction exception list, which triggers a controversial discussion on trade liberalization and food security. Additionally, the Government of China has identified a $95 \%$ self-sufficiency goal as an objective of government policy for recent years (The CCCPC and The State Council 2014).

\subsection{Agricultural productivity}

In 2008, the agricultural productivity of China was $47 \%$ of the world on an average, while only $2 \%$ of the same was recorded high-income countries (Wang 2012) indicating great disparity. Recently, the government of China introduced policies to encourage farmers to buy agricultural machinery. Inadequate irrigation system has become a serious constraint for agricultural production (Wang 2012), and the degree of agricultural mechanization is very low in China, even though China's government has subsidized agricultural machinery in recent years. Even though extensive agricultural machinery application is believed to improve productivity, this issue still needs further study in the case of China. Low rural income and the high price of machinery is another reason for the low application rate of large-scale agricultural machinery. ${ }^{1}$ The application of agricultural machinery largely depends on government subsidy (Liu 2013).

Given the present conditions in Chinese agriculture, the country appears to be on the frontline of the global food security crisis. Effective research on food security is required to ensure the national stability and to improve the well-being in China. The current study will address several key questions such as how much cultivable land is required for feeding the Chinese population in 2030 and 2050. What are the implications of meat and grain tariff reductions on China's food security in the future? Answers to the above questions are significant for the Chinese government to formulate appropriate reforms that can strengthen national food security in future decades.

The objectives of this study are to investigate China's food security situation in 2030 and investigate the impacts of alternative policies on food security. The analysis is based on a global computable general equilibrium model, which covers a large number of regions and detailed agricultural information.

The remainder of the paper is organized as follows.

Section 2 reviews methodologies that have been used in food security assessment. Section 3 calibrates Global CGE model that have been employed in the study including data and aggregation strategy and experimental design. The results of the study are presented in Sect. 4. Section 5 concludes the paper with policy recommendations.

\section{Literature review}

There are a large number of studies on food security which emphasize on food security assessment systems, food security early warning system, and estimating the relationship between food security and climate change, biofuels, and arable land. Scholars and international organizations have estimated the future impact of food security using a number

${ }^{1}$ China's agricultural production is characterized by small-peasant scale farms. Large-scale agricultural machinery is difficult to promote in rural areas. 
of alternative models. The current review includes studies that have used partial equilibrium models and computable general equilibrium models.

Partial equilibrium models consider non-agricultural markets exogenous to the system, which requires the researcher to make assumptions about the path of the macroeconomic variables in the future. The international model for policy analysis of agricultural commodities and trade (IMPACT) provides a fundamental methodology for application to the raw food market. The basic model framework includes four major components, namely food supply, food demand, price, and trade. The result of IMPACT provides information about long-term food demand and supply at a regional level (Rosegrant et al. 2008). It shows that high-meat diet in developed countries limit the improvement in food security in developing countries.

Since China became a member of the WTO, its share of world trade and foreign direct investment have grown at a faster pace However, to adapt to changes brought about by globalization, policy makers require more comprehensive models to assess policies and to forecast the impacts of policies. With the widespread application of computable general equilibrium models, a few scholars have begun to adopt single-country CGE models and multi-regional CGE models for food market. Diao et al. (2003) constructed a CGE model and used it to analyze the effects of tariff reduction on food demand and supply after China joined the WTO. Fan et al. (2008) constructed PRC-CGE model (People Republic China Computable General Equilibrium Model, PRC-CGE) to analyze the potential economic effects on China of its accession to the WTO. Zhang (2009) investigated the impact of the rapid development of the biofuel industry on national food security. The study was based on the input and output table for 2002. The study concluded that biofuel production is likely to threaten food security based on the analyses of key indicators, such as food production and food prices. DRCCGE (Dynamic Recursive Chinese CGE) model was developed by $\mathrm{Li}$ and $\mathrm{He}$ (2010) which has been widely applied by the central government to project economic growth figures for China. Huang et al. (2010a) developed China's agricultural CGE model to explore the food security of China under different agricultural technology improvement scenarios. Results of their study indicate that chemical fertilizer technology improvement has direct positive effects on grain production capacity and production cost reduction. Simulation results also reveal that if chemical fertilizer technology is improved, agricultural outputs and agricultural exports are expected to increase, while agricultural imports are likely to decrease (Huang et al. 2010a). Huang et al. (2010a) use the same CGE model to analyze agricultural subsidy policy implications on China's food security for 2020. It evaluates the food security implications of increasing agricultural subsidies. The results indicate that grain prices are expected to decrease and so also grain imports. On the other hand, grain exports are estimated to increase, respectively. The study concludes that a reduction in cultivated land is likely to result in the fluctuation of food prices and thus threaten national food security (Huang et al. 2010b).

The aforementioned models are single-country general equilibrium models. The trade partners are all aggregated into one group-"the rest of world"; therefore, these studies are lacking detailed trade information by country. Moreover, they fail to take into account the impact of trade agreements on China in general and the agriculture sector in particular. Huang and Yang (2006) adopt the GTAP model to investigate implications 
of China's food security and world food security due to the speed of economic growth in China. The simulation results indicate that import of land-intensive agricultural products (such as rice and wheat) is likely to grow. The study results show that the selfsufficiency rate of grain is expected to decline. In 2020, wheat imports for human consumption are expected to be marginal. China is likely to maintain a net export position on rice, but the export quantity is not large. The export of labor-intensive products, such as fruits, vegetables, and meat, are expected to increase. China would likely have to confront risks of national food security after entry into the WTO and unstable agricultural market prices are likely to affect farmers' income levels.

Ren (2012), on the other hand, pointed out that climate change has an impact on food security. For the varied climate condition scenarios, different grain trade policy alternatives are simulated by the GTAP-E model. The author concluded that, in 2020, China expected to have large shortages of corn, while being close to self-sufficiency in other grain commodities. Regardless of the research scenario chosen, due to rising domestic demand, imports were estimated to increase; therefore, import quotas should be adjusted. With increasing grain subsidies, grain output was expected to rise and price was predicted to decline, and thus consumers were expected to benefit. However, there would be negative impacts on farmers' incomes from the policy. Anderson and Strutt (2014) concludes that self-sufficiency rates were projected to fall more than $10 \%$ across many major agricultural products by 2030; Chinese household income and output are likely to increase, and food consumption per capita is estimated to increase as well. Food prices are likely to rise as well; however, total food consumption is estimated to decline. Therefore, government would apply alternative policies to deal with issues, such as imposing an import tax, market price intervention, and increasing public investment. Similarly, Strutt and Nelgen (2013) indicate that, if the Chinese government set $95 \%$ as the rice self-sufficiency rate, the import tariff would have to be increased substantially to protect the domestic market. Rada et al. (2013) indicate that increasing TFP is likely to improve food security rates and stimulate food production, which translates into lower food prices and greater food availability especially in Asia and Africa. Improving agricultural TFP is also likely to boost food producers' income through more trade value. Mold et al. (2014) show that south-south trade liberalization is beneficial to food security in Asia. The authors argue that current agricultural tariffs in the context of south-south trade are too high. Tariff reduction, however, is assumed to be beneficial with respect to food security in the developing world. Their results indicate that China is expected to import more food products under the tariff reduction scenario. Yu and Bandara (2014) investigate India's food security using GTAP. They argue that current government intervention for food security, such as minimal support prices, a targeted public distribution system, and centrally determined prices, is costly and not efficient. These policies generate large costs to the administrative authority. Strutt and Nelgen (2013) focused on the effects of agricultural productivity and export tariffs on food security in the Asia-Pacific regions in 2015. They found that high rice self-sufficiency rates require a high level of import restriction, but this policy is expected to lead to a lowering of household food consumption. Therefore, they pointed out that increasing TFP is likely to lead to positive food security outcomes. 
The aforementioned authors investigated China's food security from distinct perspectives, methodologies, and assumptions. Though a lot of studies have addressed the food security implications, few studies have undertaken an integrated and comprehensive assessment of China's food security situation, along with the impact of agricultural trade agreements and that of government policies on grains for the coming decades. The current study deals with these issues.

\section{Method of analysis}

The multi-regional CGE modeling framework that has been used to undertake the analysis of the current study is produced by the Center for Global Trade Analysis at Purdue University, USA. The database and model was developed for the Global Trade Analysis Project (Hertel 1997) and is essentially a multi-country multi-commodity model. The structure of the GTAP model is specified and described in Hertel (1997) and Mukhopadhyay and Thomassin (2009). The model includes industrial sectors, households, governments, and global sectors across countries where countries and regions in the model are connected by trade. Prices and quantities are generated simultaneously in both factor markets and commodity markets.

The model employs Leontief production functions and a constant return to scale (CRS) technology to produce final commodities in perfectly competitive markets. Firms minimize input costs for given levels of output and fixed technology. In the derivation of factor input demands, the model structure uses constant returns to scale technology and nested constant elasticity of substitution (CES) production functions with three levels to determine the firms' demand for primary and intermediate inputs. Intermediate input bundles are formed through a combination of imported goods and domestic goods. GTAP uses the Armington assumption to distinguish between domestic and foreign goods. ${ }^{2}$

In the GTAP model, each region or composite region has a single representative household that collects all the regional income. The household behavior is described by an aggregate utility function. The household will purchase a bundle of commodities to maximize its utility subject to given budget constraints. The consumption behavior is described by a Constant Difference Elasticity Demand System.

Demand is assumed to equal supply in all markets, which are considered to be competitive. This implies equality between the price received by the producer and the producer's marginal cost. Regional governments intervene in their own markets by imposing taxes and subsidies on commodities and primary factors, thus driving wedges between prices paid by purchasers and prices received by producers (Mukhopadhyay and Thomassin 2009). These policy interventions are modeled as ad valorem taxes, tariffs and subsidies, or quantitative restrictions in case of trade. Thus, these policies have a direct impact on the production and consumption sectors in the model.

Transportation and global banking are two global sectors in the model. The transportation sector accounts for the difference in prices of a commodity as a result of the

\footnotetext{
2 The Armington elasticity is an essential component of trade policy analysis. International trade is linked through Armington substitution among goods differentiated by country of origin. Therefore, in markets for traded commodities, buyers differentiate between domestically produced products and imported products with the same name.
} 
international freight of the good between countries and global banking brings global saving and investment into equilibrium.

Other general features of the model are its explicit recognition of savings by regional economies. These savings are completely exhausted on investments that are savingsdriven in the model. Investment in each region is financed from a global pool of savings where each region contributes a fixed proportion of its income to the savings pool (Mukhopadhyay and Thomassin 2009). In each region, there are five primary factors: skilled labor, unskilled labor, capital, land, and natural resources. The total supply of labor and land is fixed in the model, while capital is allowed to be mobile across the country depending on the rate of return for this input.

A standard GTAP model selects its exogenous variables such that there is full employment in the factor markets. This is a neoclassical approach whereby the endowments of the productive factors are fixed allowing the market prices to adjust so as to maintain full employment.

In equilibrium, all firms have zero real profit, all households are on their budget constraint, and global investment is equal to global savings. Changing the model's parameters allows one to estimate the impact from a country's/region original equilibrium position to a new equilibrium position resulting from the policy scenario under consideration.

Variables in the model are classified as being either endogenous or exogenous variables. For the model to be solved, the number of endogenous variables must be equal to the number of equations in the model. The standard GTAP closure is featured as all markets in equilibrium and all firms earn zero profits, and the regional households are on his budget constraints.

The current study was designed to aid in an investigation of China's future food security status under different policy scenarios or shocks. Thus, the model is appropriate for the study of the consequence of China's agriculture related trade policies. The interdependence of the world economy and the comprehensiveness of the GTAP framework are appropriate for the purpose of the study.

\subsection{Data and aggregation}

The study uses the GTAP version 9 database, which is based on 2011 base year (Narayanan et al. 2012). This version of the model includes 140 regions (countries) and $57 \mathrm{com}$ modities (sectors). It has been calibrated to 2011 levels of production, consumption, trade, and protection. 2011 is a good base year for the forward projection as it captures the recent temporary price spikes in both the food and energy markets, and the global financial crisis and recession (Anderson and Strutt 2014).

The 140 regions are aggregated to 17 regions with an emphasis on China and its major trading partners in agriculture goods and services. The 17 countries (regions) include Australia, New Zealand, China, Hong Kong (China), Japan, Korea, Indonesia, Thailand, Vietnam, Canada, USA, Russia, Germany, UK, Rest of Asia, ${ }^{3}$ Rest of OECD,${ }^{4}$ and Rest of

\footnotetext{
${ }^{3}$ With regard to the aggregated regions, the Rest of Asia is a separate region as it contains some Asian countries that a naturally trading partners with China due to location, but also countries that do not have a large trading value with China.

4 The Rest of OECD is separated from the Rest of World because of their distinct development stages that may influence their trade relationships and specific composition of trade with China.
} 
world. The individual countries on the list are China's traditional major trading partners. Given the agricultural emphasis of this study, there is no aggregation of agricultural sectors, food sectors, and industries related to agricultural sectors, while the other nonagriculture sectors are aggregated. The 57 industry sectors have been aggregated to 36 sectors on the basis of trade intensiveness in China.

\subsection{Modifications of GTAP model}

In order to undertake the desired projection and simulation exercises, a decision was made that the static GTAP model with a base year of 2011 was to be updated to the projection year 2030. ${ }^{5}$ For the purposes of model updating, this study uses the recursiveupdating process that is based on forecasting the countries' (regions') economies by exogenously shocking the baseline model with projections of macroeconomic variables. The first step in the modeling process is the generation of a Business as Usual (BAU) projection from the benchmark 2011 GTAP 9 database. New economies can be generated for the years 2011-2020, 2020-2030, and 2030-2050 using macroeconomic shocks for the key variables The exogenous macrovariable shocks include capital, population, skilled labor, unskilled labor, and total factor productivity. The projection of growth rate for total factor productivity for non-agricultural sectors is sourced from CEP II (Fouré et al. 2010). The growth rate for total factor productivity for the agricultural sectors is based on the estimation work of Ludena et al. (2007). The population growth rate projection was taken from the United Nations publication; 2012 Revised Population database, United Nation, Population Division. The growth rates for skilled labor, unskilled labor, and capital are also taken from CEP II (Fouré et al. 2010). GDP is endogenously determined to accommodate the combination of these exogenous shocks.

\subsection{Experimental design}

There are a few scenarios investigated for this study. These are: business as usual, tariff adjustment free trade agreements, and other agricultural policy interventions.

1. This BAU scenario projection is developed to provide a picture of how the global economy and world trade might look with the current tariff barriers. Taking 2011 as the base year and using macroeconomic shocks to generate a new economy for 2020, 2030, and 2050. It provides a baseline against which a comparison may be made for the implementation of the various scenarios under study such as the implementation of trade agreements, tariff reductions, and other agricultural policy interventions.

2. There are five experiments in the tariff scenarios. The first experiment is a meat tariff reduction (MTR). It describes a situation where import tariffs for all meat and livestock sectors are removed. Some people argue that to improve grain self-sufficiency, China could and perhaps should import more meat. They believe that if China imports more meat, domestic meat production will decline along with feed grain use. Since feed grain and food grains compete for natural resources, such as water and land, if demand for feed grain decreases, more resources will be allocated to food

\footnotetext{
${ }^{5}$ It is known that China's government agencies are particularly interested in certain variables, such as arable land requirements in 2050 under 95 and 90\% self-sufficiency rates, and grain self-sufficiency rates for the same year. Thus these are the key food security variables from the perspective of China's government. For the estimation of the arable land requirement and the grain self-sufficiency rates, the study provides estimates for these variables to 2050 . For the other model variables, the projections are made to 2030.
} 
grain sectors such as wheat and rice. Therefore, the objective of this experiment is to investigate the effects of meat tariff reductions on grain self-sufficiency rates. The second experiment concerns grain tariff reductions (GTR). This would be the case if China was to open its grain markets to competition and eliminate the protection that the grain sectors receive. At the present, China imposes higher import tariffs for grain products than for other agricultural commodities to maintain a high grain self-sufficiency rate. The third experiment would impose a high grain tariff (GTI) to protect domestic grain producers and thus to encourage a high grain self-sufficiency rate. The last two experiments in the tariff scenarios are related to the recent free trade agreements under negotiation. Since Australia is expected to become new Asia food supplier due to abundant natural resources and low domestic food demand, the fourth experiment, which is China and Australia free meat trade agreement (CAM), focuses on Australia. It explores the effects of import tariff removal for meat and livestock entering China. On the other hand, Korea Republic is one of the main meat export markets for China. The Korean government sets high tariffs for agricultural goods to protect their domestic agriculture from international market effects. Both countries, China and Korea, agreed to have free trade negotiations in November 2004. Currently, the two countries are negotiating several sensitive issues such as agricultural tariffs. This experiment China and Korea free meat trade agreement (CKM) describes a situation where Korea removes all meat tariffs for meat imported from China.

3. In the 12th Five-Year Plan (2010-2015), the central government of China sets the annual grain growth rate as $2.04 \%$ to meet its grain output target. The last two experiments describe the implications for China and her trading partners if China keeps mandated growth rates for rice (MRG) and for wheat (MWG) over the study period until 2030.

The above scenario descriptions require a change in the development of the GTAP model to undertake the simulation. The descriptions of those scenarios are presented in Table 1.

\section{Analysis of results}

The results and economic analyses are presented in the business as usual (BAU) scenario for 2030 and $2050^{6}$ and various other scenarios in this section. The important food security indicators in different scenarios and the BAU scenario are discussed, such as output growth, export and import growth, self-sufficiency rates, food prices, and private food consumption. In addition, the study presents a discussion on welfare implications and GDP effects and returns to unskilled labor associated with each scenario.

\subsection{BAU scenario}

\subsubsection{Output growth}

China is expected to have the highest GDP growth rate in the period between 2011 and 2020 at approximately $7.3 \%$ per year, and at 5\% per year in the period $2020-2030$.

\footnotetext{
$\overline{{ }^{6} \text { Since arable land use and grain self-sufficiency rates are emphasized by China's central government, it was deemed }}$ important for this study to focus on future trends of these two variables. Therefore, the study presents analyses of these two variables to 2050 , and to 2030 for the rest of the food securities.
} 
Table 1 Simulation description

\begin{tabular}{|c|c|c|c|c|c|}
\hline Simulation block & Simulation & Meat sectors & Rice sector & Wheat sector & Grain sectors $^{a}$ \\
\hline \multirow{5}{*}{$\begin{array}{l}\text { Tariff adjustment } \\
\text { and free trade } \\
\text { agreement } \\
\text { block }\end{array}$} & MTR & Remove tariff & & & \\
\hline & GTR & & & & Remove tariff \\
\hline & GTI & & & & $\begin{array}{l}\text { Increase tariff by } \\
50 \%\end{array}$ \\
\hline & CAM & $\begin{array}{l}\text { Remove tariff } \\
\text { for meat from } \\
\text { Australia }\end{array}$ & & & \\
\hline & CKM & $\begin{array}{l}\text { Korea removes } \\
\text { tariff for meat } \\
\text { from China }\end{array}$ & & & \\
\hline \multirow[t]{2}{*}{$\begin{array}{l}\text { Government man- } \\
\text { dated growth } \\
\text { rate }\end{array}$} & MRG & & $\begin{array}{l}\text { Mandated growth } \\
\text { rate is } 18.34 \% \\
\text { p.a } a^{b}\end{array}$ & & \\
\hline & MWG & & & $\begin{array}{l}\text { Mandated growth } \\
\text { rate is } 18.34 \% \\
\text { p.a }\end{array}$ & \\
\hline
\end{tabular}

a Grain sectors include wheat, rice, and other grain sectors in the GTAP database

b In the 12th Five-Year Plan, the government sets the grain production target as 540 million tonnes in 2015; therefore, the mandated grain growth rate is $18.34 \%$ per year during the period from 2011 to 2015 . Since rice and wheat both are important grain products for China, two simulations (for rice and wheat) are undertaken in the study

Results indicate that live cattle, beef meat products, plant-based fibers, other grain products, and rice are the most important sectors in terms of their industrial output growth. The ranking remains almost constant in each BAU scenario period. In general, the actual level of output for all agricultural commodities is expected to increase, while the annual growth rate of output for the majority of agricultural commodities is expected to decline over time. For example, the output growth rate for grain is estimated to decline. For the livestock sectors, other animal products, beef products are likely to decline by the greatest amount. Output of vegetables and fruits commodities is likely to grow at a decreasing rate in the future. China's domestic oil seed output is expected to rise at a decreasing rate during the study period.

\subsubsection{Self-sufficiency rates}

China's government has increased grain self-sufficiency rates over time and is the main food security indicator identified by the central government. More importantly given the dominant position held by rice and wheat as staple foods for Chinese consumers, the government has expressed a commitment to being self-sufficient in rice (Qian 2014). In the 12th Five-Year Plan, the government sets a 95\% self-sufficiency rate for rice and wheat as an objective to maintain food security (Qian 2014). Corn is also another important grain product for the country and is generally used as an animal feed. In the GTAP's grain classification, corn is included in the "another grain group."

A number of studies on China's food security have estimated the country's grain deficit $^{7}$ (Brown 1994; Chen 2004, 2012; Chen et al. 2010; Huang and Jiabao 1997; Kang 1998). It is useful to make a comparison of their results with the current study's results; therefore, the balance of grain demand and supply will be discussed first. In terms of

\footnotetext{
${ }^{7}$ As the quantity results in other studies appear as percentage changes year by year, the first step is to construct 2013 quantities, which are from the Statistical Yearbook of China. From these quantities the percentage grain growth rate is extracted from GTAP's results. This allows for one to project production and consumption values.
} 
Table 2 Projection results of grain self-sufficiency rates. Sources: results from the study

\begin{tabular}{llll}
\hline Grain items & $\mathbf{2 0 2 0}(\mathbf{\%})$ & $\mathbf{2 0 3 0}(\mathbf{\%})$ & $\mathbf{2 0 5 0}(\mathbf{\%})$ \\
\hline Rice & 98.61 & 95.05 & 82.25 \\
Wheat & 96.8 & 93.82 & 84.97 \\
Other grain & 96.46 & 92.09 & 79.89 \\
\hline
\end{tabular}

value, the projected results for 2020 show that total grain production will be 673.40 million tons and that total grain consumption will be 692.878 million tons. Thus the grain deficit will be almost 20 million tons in $2020 .{ }^{8}$ Grain output is predicted to expect a significant increase but cannot offset the large consumption growth rate, even then. The possible reasons for the considerable grain consumption increases are industrial uses in brewing alcohol, starch production, and the pharmaceutical industry. According to the BAU projection results (Table 2), self-sufficiency rates ${ }^{9}$ of rice, wheat, and other grain products are $98.61,96.8$, and $96.46 \%$ in 2020 , respectively. In 2030 , the self-sufficiency rate in rice is $95.05 \%$, which is just at the government target. Wheat's self-sufficiency rate is $93.82 \%$, which is below the government target. Other grain product's self-sufficiency rate is $92.09 \%$. The results are consistent with other studies' results, such as Chen (2012).

The gap between production and consumption for corn will grow gradually; therefore, the self-sufficiency rate of other grain is likely to fall at the fastest rate. Since feed uses and industry uses are expected to grow at a rapid rate, corn's domestic demand will increase much faster than its domestic supply. In the year 2050, all grain products are expected to fall below the government targets. Rice self-sufficiency will be only $82.25 \%$ and wheat self-sufficiency rate will be just $84.97 \%$, whereas corn self-sufficiency will be less than $80 \%$.

From 2020 to 2030, rice's output is expected to increase by $42 \%$, and its consumption is estimated to rise by $47 \%$; therefore, the rice deficit is projected to increase substantially from 2.88 million tons in 2020 to 15.118 million tons in 2030. The rice deficit is estimated to be even larger in 2050. Similarly, the wheat demand (124.28 million tons) in 2013 is expected to increase to 246.7 million tons $(98 \%)$ in 2030 and 359.876 million tons (190\%) in 2050, respectively. Demand is expected to grow faster than supply, so the wheat deficit will keep increasing throughout the projection years. The deficit is likely to be 15.12 million tons, and 54.08 million tons in 2030 and 2050 respectively. The current study shows the corn deficit ${ }^{10}$ to be about 11.057 million tons, 37.536 million tons, and 310.664 million tons in 2020,2030, and 2050, respectively. The results indicate that corn accounts for the majority of grain imports in the future. Corn is not a dominant staple food for China, but it is major feed crop. As income grows, demand for meat and livestock products bring substantial pressure on corn demand. Self-sufficiency rates for oil seeds, vegetable oils, and fats are expected to decrease over the projection periods. The results are also consistent with other studies' results.

\footnotetext{
8 This result is lower than the projection results of the National Food Grain Security medium- and long-term plan for 2008-2020 (32.5 million tons); FAO (60.5 million tons); Brown (258.4 million tons) IMPACT (41.1 million tons) (Brown 1994; Chen et al. 2010; Kang 1998).

9 The self-sufficiency rate is calculated by production divided by consumption.

10 The corn deficit is expected to be 17.25 million tons in 2020 in Chen's study.
} 


\subsubsection{Import and export}

China is expected to expand total import and export value in 2030. The trade deficit is expected to grow to 1674,207 million US dollars for the same period. The study estimates the comparison for shares of the trading partners between 2011 and 2030. Canada is becoming a more and more important trade partner with China. Australia and New Zealand account for only $1.09 \%$ of China's total imports in 2030, although they still have a great potential for growth. Russia is expected to account for $3.31 \%$ of China's total imports. The USA is likely to replace Japan to become the largest international supplier for China along with rest of Asia. Shares of Korea and Japan are estimated to decline significantly from 2011 to 2030. The BAU results indicate that China's import partners are expected to be more diverse in 2030 than in 2011 which are assumed to be good for China. This is because trade partner diversification might provide cheaper goods and thus favor trade policies for China.

The export markets are also likely to be more diverse in 2030 than 2011. The Rest of OECD is expected to account for the majority of China's exports (34.2\%) in 2030, which is followed by the USA (16.67\%) and Germany (5.18\%). Overall, China is expected to expand its export markets to the rest of OECD countries and the Rest of World.

Regarding agricultural trade, both agricultural exports and imports by China are expected to increase substantially by 2030. The results of the analysis show that China's agricultural imports are expected to be higher than agricultural exports over the whole projection period, and thus the agricultural trade deficit is predicted to rise. According to the results, exports of agricultural products and light manufacturing's are expected to increase. On the import side, machinery and equipment are expected to replace light manufacturing on the import ranking. The ranking of the rest of the top six imported sectors ${ }^{11}$ is likely to remain constant for the BAU scenario.

The current study determines that the highest import growth rates are expected to be for the meat and live animals' sectors. Oilseeds and vegetable oils and fats are still the predominant imported agricultural commodities in 2030. The import of grain products is expected to grow rapidly in the coming decades. The import share of animal products is estimated to remain relatively constant throughout the BAU period.

The export shares for vegetables and fruits and animal products are expected to decline during the study period. Otherwise, fishery products, grain products, and fat and oil products are likely to have a stable share during the 2013-2030 period.

\subsubsection{Arable land requirement ${ }^{12}$}

According to the BAU, total wheat and rice consumption for 2020 and 2030 are 692.88 million tons and 1027.063 million tons, respectively. The following arable land estimation assumes that the productivity of each unit of land is constant at the 2013 level. If the self-sufficiency rates for rice and wheat are $90 \%$, the minimal sown areas ${ }^{13}$ for rice and

\footnotetext{
11 The top import sectors include light manufacturing, petroleum, coal products, chemical, rubber, plastic products, other heavy industries, machinery and equipment and manufactory.

12 Since arable land "Red Line" policy provides a critical point of arable land, the study aims to assess whether this critical points are sufficiency to ensure high grain self-sufficiency rates in long term. Therefore, minimal arable land requirement estimation is projected up 2050

13 The minimal rice and wheat area calculations are determined by the following procedure: (a) use rice and wheat sown areas in 2013 and outputs of rice and wheat in 2013 to calculate output per unit of land; (b) the required output can be calculated by projected consumption taking into account required self-sufficiency rates; (c) the minimal required arable land is calculated by required output divided by output per unit land.
} 
Table 3 Minimal arable land requirements. Sources: results from the study

\begin{tabular}{lrr}
\hline & \multicolumn{1}{c}{$\mathbf{2 0 3 0}$} & \multicolumn{1}{c}{$\mathbf{2 0 5 0}$} \\
\hline Consumption in tons (000) & $1,027,063$ & $1,694,194$ \\
Production (90\% self-sufficiency rate) & 497,062 & 770,001 \\
Land requirement in mu (000) & $1,760,693$ & $2,727,194$ \\
Production (95\% self-sufficiency rate) & 524,677 & 812,779 \\
Land requirement in mu (000) & $1,858,509$ & $2,879,022$ \\
\hline
\end{tabular}

wheat are estimated to be 1212.983 million $\mathrm{mu}^{14}$ in 2020 and 1760.693 million mu in 2030 and 2727.194 million mu in 2050 (Table 3). After 2030, the current arable land "Red Line" policy, conserving China's arable land above 1800 million mu, is not enough to achieve a $90 \%$ grain self-sufficiency rate. With a $95 \%$ self-sufficiency rate for rice and wheat, the minimal sown areas of rice and wheat are calculated to be 1280.37 million $\mathrm{mu}, 1858.509$ million mu, and 2879.022 million mu in 2020, 2030, and 2050, respectively. The higher self-sufficiency rate needs more arable land. Therefore, in 2030, the required sown areas for a 95\% self-sufficiency rate for rice and wheat are higher than "Red Line" (1800 million $\mathrm{mu}$ ) by 58,509 million $\mathrm{mu}$.

According to the BAU results analyses, without any agricultural productivity advancement, China is unable to achieve its grain self-sufficiency targets in 2030 and 2050. In addition, the current "Red Line" policy is not enough to produce sufficient grain to meet the $95 \%$ grain self-sufficiency rate. Thus, the arable land conservation policy should be strengthened, but it is just partial solution. Meanwhile, other agricultural policy alternatives, such as agricultural trade policy and agricultural support policy, should be attempted to improve food security.

\subsection{Tariff scenarios}

First, the study looks at the how tariff and trade policies impact China's food security. Under this block, the study looked at five experiments. The analysis will be presented in the order of three tariff adjustments experiments and two free trade agreement experiments.

\subsubsection{Output growth rate}

The output growth rates in 2030 under different tariff adjustment scenarios are presented in Table $4 .{ }^{15}$ A reduction in the meat tariff (MTR) has a small impact on agricultural sectoral output in 2030, compared with BAU 2030. As expected, sectoral output of beef cattle, sheep and goats, horses, and beef meat products were adversely affected. The beef meat product output growth rate is also expected to be lower than it is in the BAU. However, other animal products and other meat products are found to have increased output levels with the meat tariff reduction policies, which are 1.7 and $2.9 \%$, respectively. This occurred because the import of beef animal products and beef meat products are higher than for other animal and meat products. Therefore, production of beef animals and meat products shrink, so as to release more production resources as compared to other meat

${ }_{14} \mathrm{Mu}$ is China's land unit. $1 \mathrm{mu}=0.067$ hectare. China's "Red Line" of arable land is 1,800 million mu.

15 In the table, "-" indicates decline and "+" indicates increase. The rest tables follow the same rule. 
Table 4 Output growth rate changes compared with BAU. Sources: results from the study

\begin{tabular}{llcc}
\hline Sectors & MTR 2030 & GTR 2030 & GTI 2030 \\
\hline Rice & + & + & - \\
Wheat & + & - & + \\
Other grain products & - & - & + \\
Vegetables and fruits & - & + & - \\
Oil seeds & - & + & - \\
Bovine cattle, sheep, and goats & - & + & - \\
Other animal products & + & + & - \\
Fishery products & + & + & - \\
Bovine meat products & - & + & - \\
Other meat products & + & + & \\
Vegetable oils and fats & - & + & \\
\hline
\end{tabular}

sectors. Therefore, the other animal and meat sectors show increased levels of output. For rice and wheat, the output levels are expected to increase marginally. Other grain products are expected to have decreased output levels. These results appear to be because of the meat import expansion which leads to a decreased feed grain demand domestically. Thus more land and input factors are available for the wheat and rice sectors. The results indicate that the meat tariff reduction intervention is likely to have negative effects on other agricultural sector outputs, but they are not significant. For the grain tariff reduction (GTR), compared to the output growth rate in the BAU at 2030, the wheat sector and other grain sectors are expected to see a decrease in their output levels. The rice sector is likely to increase its output level. Since China is very good at producing rice, any grain tariff reduction is expected to have little effect on domestic rice production levels. The other agricultural sectors are likely to show a slight, but insignificant increase in output level. In the scenario of increasing the grain tariff (GTI), compared with output growth in the BAU at 2030, wheat and other grain product output growth rates are likely to increase by 1.2 and $1.9 \%$, respectively, while the rest of the agricultural sectors, including the rice sector, are found to have slight declines in output levels.

Since these two experiments (CAM and CKM) only shock the animal and meat sectors in one country, the changes in other agricultural sectoral outputs between the BAU scenario and the free trade agreement scenarios are insignificant. If China removes a meat import tariff for the meat imported from Australia, all meat sector outputs are expected to decline. The beef meat sectors are expected to experience the largest impacts on output growth rates. If Korea removes the meat import tariff from China, China's meat sector outputs are expected to increase because of an increase in export demand. Beef meat and other meat sectors are most impacted in the CKM 2030 scenario.

\subsubsection{Self-sufficiency rate ${ }^{16}$}

Self-sufficiency rates are very important food security indictors for China's government. They believe the grain sufficiency rate must be higher than $95 \%$. Table 5 summarizes

${ }^{16}$ Since current study is particularly interested in grain sufficiency rates, study will project for grain self-sufficiency rates upto 2050 
Table 5 Self-sufficiency rate for grains in 2030 and 2050 in various scenarios compared with BAU. Sources: results from the study

\begin{tabular}{llll}
\hline Simulation exercises & Rice & Wheat & Other grain \\
\hline The self-sufficiency rate for grain in 2030 compared with BAU 2030 & & \\
MTR & $1.84 \%$ & $1.69 \%$ & $1.84 \%$ \\
GTR & Negligible & Negligible & Negligible \\
GTI & $3.76 \%$ & $3.44 \%$ & $3.76 \%$ \\
CAM & $0.04 \%$ & $1.69 \%$ & $1.84 \%$ \\
CKM & Negligible & Negligible & Negligible \\
The self-sufficiency rate for grain in 2050 compared with BAU 2050 & & \\
MTR & $8.11 \%$ & $8.49 \%$ & $7.76 \%$ \\
GTR & Negligible & Negligible & Negligible \\
GTI & $18.03 \%$ & $19.17 \%$ & $18.18 \%$ \\
CAM & $8.09 \%$ & $8.61 \%$ & $7.77 \%$ \\
CKM & Negligible & Negligible & Negligible \\
\hline
\end{tabular}

changes in self-sufficiency rates for grain under tariff adjustment scenarios in 2030 and 2050, compared with the BAU at 2030 and 2050. If the government removes the meat tariff, the self-sufficiency rate for all grain products is likely to increase. Rice's self-sufficiency rate is expected to increase from $95.05 \%$ in BAU 2030 to $96.89 \%$ in MTR 2030. Regarding wheat, a meat tariff reduction (MTR) is expected to bring positive effects on self-sufficiency rates. In 2030, the wheat self-sufficiency rate is likely to increase from 93.82\% in the BAU to $95.51 \%$ in the MTR. For both rice and wheat, the self-sufficiency rates with a meat tariff reduction policy will be higher than the government's grain security target. For other grains, such as corn, the self-sufficiency rate is expected to rise from $92.09 \%$ in the BAU 2030 to $93.93 \%$ in the MTR 2030. The other grain selfsufficiency rates are 92.09 and $79.89 \%$ in the BAU 2030 and 2050 scenarios, respectively. They are expected to increase by 1.84 and $7.76 \%$ in the MTR 2030 and 2050 scenarios, respectively.

For 2050, the positive effects of the meat tariff reduction policy are more obvious. The self-sufficiency rates for rice and wheat in the BAU 2050 scenario are much lower than government food security targets, while in the MTR 2050 scenario, both of the self-sufficiency rates are above $90 \%$. In general, a meat tariff reduction is likely to enhance the grain self-sufficiency rates in all projection periods.

The results show that a grain tariff reduction does not have significant effects on grain self-sufficiency rates. However, for a grain tariff increase, the self-sufficiency rates for all grain commodities appear to indicate a considerable increase in 2030 and 2050. For instance, the rice self-sufficiency rate is expected to increase from 95.05 to $98.81 \%$ in 2030. Wheat has similar results. In 2030, the wheat self-sufficiency rate is $93.82 \%$ for the BAU in 2030, while it is expected to increase to $97.26 \%$ for the grain tariff increase in 2030. The other grain product self-sufficiency rate is expected to be higher than it is in the BAU scenario as well. In 2030, compared with the BAU, the other grain's selfsufficiency rate is expected to increase by about $3.75 \%$ if the grain tariff increases by $50 \%$.

All the grain product self-sufficiency rates are lower than $90 \%$ in the BAU 2050 scenario, while rice, wheat, and the other grain self-sufficiency rates are expected to improve to 100,104 , and $98 \%$, respectively for a grain tariff increase in 2050 . The self-sufficiency 
rates for all the grain products are likely to be above government targets under the grain tariff increased scenario by 2050. Generally speaking, a grain tariff reduction does not have significant effects on self-sufficiency rates, while a grain tariff increase raises China's grain self-sufficiency rates considerably. On its own, self-sufficiency is not a perfect food security indictor. To fully access a country's food security status, the government also needs to take private consumption levels and food prices into consideration.

The rice and wheat self-sufficiency rates have been improved to target levels in the CAM 2030 scenario (Table 5). The self-sufficiency rates for rice and wheat are expected to reach 95.10 and $95.51 \%$ in 2030 , respectively. Other grain self-sufficiency rates are likely to increase from $92.09 \%$ in the BAU 2030 scenario to $93.93 \%$ in the CAM 2030 scenario. For 2050, the self-sufficiency rates for rice, wheat, and other grains are expected to reach $90.34,93.58$, and $87.67 \%$, respectively. As expected, meat import expansion is helpful to free more natural resources to rice and wheat sectors from feed grain production. Compared to the BAU 2030 scenario, Korea's free trade in meat does not change China's grain self-sufficiency rates in both 2030 and 2050. This results because Korea accounts for a relatively small share of China's meat export share in 2030; therefore, its trade policy impacts on China's grain self-sufficiency rates are negligible.

\subsubsection{Import and export}

The growth rate of import ranking is fairly constant for three scenarios (MTR, GTR, and GTI) compared with the BAU 2030 scenario (Table 6). Comparing import growth rates between the BAU and the MTR 2030, the same for beef animals, other animal products, beef meat products and other meat products are expected to increase by 3.27, 8.93, 15.48, and $32.71 \%$, respectively. The import growth rates for rice, wheat, and other grains are expected to decline by $2.6,2.7$, and $0.4 \%$, respectively, resulting in feed grain and livestock products production to also decline. The interaction process is as follows: When the livestock sectors increase their production levels, more feed grain is required. Import and domestic production of feed grains are expected to expand. Meanwhile, feed grain (corn) and food grain (rice and wheat) compete for production resources. When more endowment factors are shifted into the feed grain sector, domestic food grain production and the resulting output level will shrink. Therefore, the import of food grain products is expected to increase. In the case of a meat tariff reduction, the government removes meat and live animal import tariffs, so the domestic livestock production levels are expected to encounter decline due to an increase in imported goods. The other sectors, with small percentage decreases in import levels, are not expected to be affected significantly.

As expected, a grain tariff reduction (GTR) is likely to encourage an increase in grain imports. Compared to the grain import growth rate in the BAU at 2030, a grain tariff reduction is expected to increase rice imports from 5461 million tons (BAU 2030) to 5150.3 million tons (GTR 2030) and increase wheat imports from 6836 million tons (BAU 2030) to about 7119 million tons (GTR 2030). For other grain products, the import quantity is likely to increase from 5194.6 million tons (BAU 2030) to 5285.7 million tons (GTR 2030). On the contrary, a grain tariff increase (GTI) is expected to reduce grain imports by a small amount. For example, compared to the BAU 2030 scenario, the import growth rate for rice, wheat, and other grain products in the GTI 2030 scenario are likely to decline by $1.9,1.72$, and $1.89 \%$, respectively. 
Table 6 Import growth rate change in 2030 compared with BAU 2030. Sources: results from the study

\begin{tabular}{|c|c|c|c|}
\hline Import & MTR 2030 & GTR 2030 & GTI 2030 \\
\hline Rice & - & + & - \\
\hline Wheat & - & + & - \\
\hline Other grain products & - & + & - \\
\hline Vegetable and fruits & - & - & + \\
\hline Oil seeds & - & + & - \\
\hline Bovine cattle, sheep, and goats, horses & + & - & + \\
\hline Other animal products & + & - & + \\
\hline Fishery products & - & + & - \\
\hline Bovine meat products & + & - & + \\
\hline Other meat products & + & - & + \\
\hline Vegetable oils and fats & - & - & + \\
\hline
\end{tabular}

On the export side, a meat tariff reduction is expected to increase exports for the majority of agricultural products, except for fishery products. Compared with the BAU 2030 scenario, rice, wheat, and other grain product output levels are expected to increase by $3.47,4.87$, and $1.06 \%$, respectively (Table 7). An interesting, and at first glance, counterintuitive result is shown in the beef meat, beef animal, other animal, and other meat sectors. These sectors are projected to have positive export growth rates for the MTR 2030 scenario. Thus China is likely to import more live animals in the MTR 2030 scenario, and at the same time the country will also export more processed meat in the MTR 2030 scenario.

Grain tariff changes do not result in significant effects on agricultural exports, including the rice, wheat, and other grain sectors. It is interesting that grain exports in the GTR 2030 scenario are less than they are in the BAU 2030 scenario, and grain exports in the GTI 2030 scenario are higher than they are in BAU 2030. It is likely because China imports more grain products due to the grain tariff reduction. There is sufficient grain supply in the domestic market, so China is expected to have extra grain to export. In the GTI 2030 scenario, it is the opposite case than the GTR scenario. The majority of domestic grain production has to be allocated to the domestic market, so there is less remaining for the export market. The changes in the export growth rates for the agricultural sectors due to grain tariff adjustment policies are lower than $1 \%$, compared with the BAU 2030 scenario.

Meat trade liberalization is expected to have different impacts on exports and imports. The study addresses the export and import changes under the BAU and different trade agreement scenarios. In the CAM 2030 scenario compared with the BAU 2030 scenario, export increases for most agricultural sectors, such as the grain, vegetables and fruits, sugar, plant-based fibers, milk, wool, vegetable oils and fats, and the dairy product sectors. For imports, the impacts on each agricultural sector are different. For instance, grains, vegetables and fruits, and the vegetable oils and fats sectors are expected to decrease their imports. Compared with the BAU 2030 scenario, imports of rice, wheat, and other grains are likely to decrease by $3,2.9$, and $1.6 \%$, respectively. Imports of vegetables and fruits are estimated to decrease by $2.4 \%$, while import of vegetable oils and fats is likely to decline by $1.8 \%$. The reason is similar to that of the results for the MTR 
Table 7 Export growth rate change in 2030 compared with BAU 2030. Sources: results from the study

\begin{tabular}{llll}
\hline Export & MTR 2030 & GTR 2030 & GTI 2030 \\
\hline Rice & + & + & - \\
Wheat & + & + & - \\
Other grain products & + & + & - \\
Vegetable and fruits & + & + & - \\
Oil seeds & + & + & - \\
Bovine cattle, sheep, and goats, horses & + & + & - \\
Other animal products & + & - & - \\
Fishery products & - & + & - \\
Bovine meat products & + & + & - \\
Other meat products & + & + & \\
Vegetable oils and fats & + & & \\
\hline
\end{tabular}

scenarios. For oilseeds, other crops, and other meat products, both exports and imports are expected to be higher than they are in the BAU 2030 scenario, but exports are estimated to grow faster than imports. For the other meat sectors, including beef animal sectors, other animal sectors, and other meat sectors, the import growth is higher than export growth in the CAM 2030 scenario. Overall, China's tariff reduction for Australian and New Zealand meat products could expand China's agricultural exports.

In the CKM scenario, the other meat product sector is most affected. Its export growth rate is expected to increase by $29.6 \%$. The rest of the agricultural sectors do not exhibit significant effects. Overall, the import growth rate has increased slightly in the CKM 2030 scenario. If Korea increases meat demand from China, China needs to import more food to meet domestic consumption requirements. China's exports decrease in the grain, vegetables and fruits, oil seeds, sugar, plant-based fibers, other crops, milk and dairy products, and fishery products sectors. Compared with the CKM scenario, the CAM scenario is more favored in terms of China's agricultural trade surplus in 2030 (Table 8).

\subsubsection{Private consumption and food price}

Compared to private consumption levels in the BAU 2030 scenario, private consumption levels for the majority of agricultural commodities are expected to increase in the MTR 2030 scenario, particularly for other grain products $(1.34 \%)$, oilseeds $(2.69 \%)$, vegetables and fruits $(1.34 \%)$, dairy products (2.21\%), beef animals (3.12\%), and beef meat products (1.3\%). More interesting results are observed for the other meat sector products. Chinese consumers decrease their consumption for other meat products by $2.7 \%$. Overall, private consumption is expected to increase for the majority of goods. The MTR scenario is expected to encourage Chinese consumers to increase their food consumption due to lower food prices, so that national food security is expected to improve under the MTR scenario (Table 9).

Grain tariff changes are expected to have little effect on private food consumption levels. Overall, a grain tariff reduction is expected to increase food consumption levels for the majority of agricultural good only slightly, while a higher grain tariff is predicted to decrease food consumption levels. 
Table 8 Import and export changes of CAM and CKM 2030, compared with BAU 2030. Sources: results from the study

\begin{tabular}{|c|c|c|c|c|}
\hline \multirow[t]{2}{*}{ Sectors } & \multicolumn{2}{|c|}{ CAM 2030} & \multicolumn{2}{|c|}{ CKM 2030} \\
\hline & Import & Export & Import & Export \\
\hline Rice & - & + & + & - \\
\hline Wheat & - & + & + & - \\
\hline Other grain products & - & + & + & - \\
\hline Vegetable and fruits & - & + & + & - \\
\hline Oil seeds & + & + & + & - \\
\hline Bovine cattle, sheep, and goats, horses & + & + & + & + \\
\hline Other animal products & + & + & + & + \\
\hline Fishery products & + & + & + & - \\
\hline Bovine meat products & + & + & + & + \\
\hline Other meat products & + & + & + & + \\
\hline Vegetable oils and fats & - & + & + & - \\
\hline
\end{tabular}

Table 10 shows results of the simulation for changes in commodity prices. Generally speaking, tariff reduction policies are likely to decrease food prices, resulting in the food becoming more accessible for poor people. In the case of the GTI scenario, food prices are likely to increase for the majority of food products, but the resulting changes are not expected to be significant. Comparing the GTR 2030 scenario with the BAU 2030 scenario, most food prices are expected to decrease slightly. For the MTR 2030 scenario, grain product prices are likely to decrease by $0.36-0.54 \%$ compared to the BAU 2030 scenario, resulting in less domestic demand for feed grains. The price for beef animal products and other animal products are expected to decrease by 0.46 and $0.72 \%$ in 2030 , respectively. The most significant effect is shown in the beef meat sector, where the price is estimated to be reduced by $1.34 \%$. Compared to the BAU 2030 scenario, other meat product prices are likely to decrease by $0.78 \%$. Overall, grain tariff changes are expected to have little impact on food prices while meat tariff reduction is expected to have noticeable impacts on the price of livestock and grain products.

The impacts of the meat free trade agreement (CAM and CKM) on domestic private food consumption and food prices indicate that all agricultural commodity prices in

Table 9 Private consumption change in 2030, compared with BAU 2030. Sources: results from the study

\begin{tabular}{lccc}
\hline Sectors & MTR 2030 & GTR 2030 & GTI 2030 \\
\hline Rice & + & + & + \\
Wheat & + & + & - \\
Other grain products & + & + & + \\
Vegetable and fruits & + & + & - \\
Oil seeds & + & + & - \\
Bovine cattle, sheep, and goats, horses & + & - & - \\
Other animal products & + & + & + \\
Fishery products & + & + & - \\
Bovine meat products & + & + & - \\
Other meat products & - & + & - \\
Vegetable oils and fats & + & & \\
\hline
\end{tabular}


the CAM 2030 scenario are expected to be lower than they are in the BAU 2030 scenario (Table 11). Since the government loosens meat import restrictions, the subsequent expansion leads to an increase in domestic supply level which is likely to depress domestic meat prices. Prices of other agricultural sectors also are impacted indirectly. Compared to the BAU 2030 scenario, all agricultural sector prices are higher for the CKM 2030 scenario. If Korea removes meat import tariffs for China's meat products, China's meat exports are expected to increase. Meanwhile, livestock production is likely to expand to meet international demand. Meat and animal products are expected to attract more natural resources and labor, and therefore, other agricultural sectors have to face increasing endowment factor prices. As a result, the production in those sectors is likely to decrease. In general, other agricultural commodity prices are likely to increase due to rising input costs.

Compared to the BAU 2030 scenario, domestic household consumption in the CAM 2030 scenario for a majority of agricultural commodities is likely to increase, except for other animal products and other meat products. Intriguing as these findings are, per capita consumption of other animal products and other meat products is likely to decrease, even though their price decreases. This could be due to the price reduction in those sectors not being significant and consumers allocating their food budgets to other products, which have significant price reductions. Compared to the BAU 2030 scenario, domestic household food consumption is expected to decline by a small degree under the CKM 2030 scenario. The domestic consumption decrease is in all probability caused by increasing product prices in the CKM scenario.

\subsection{Mandated rice and wheat growth rate}

\subsubsection{Output growth}

The output growth rate, in the rice mandated growth rate (MRG) scenario, is expected to be $20.6 \%$ higher than it is in the BAU 2030 scenario. The wheat and other grains sectors are expected to have higher output growth than the rice sector, approximately 35.1 and $21.5 \%$, respectively. The results suggest that the other agricultural sectors' yields are expected to rise as well. For the beef animals, other animals, beef meat products, and other meat sectors output levels are likely to increase by $17.4,34.3,26.7$, and $48.3 \%$,

Table 10 Sectoral price change in 2030, compared with BAU 2030. Sources: results from the study

\begin{tabular}{llll}
\hline Sectors & MTR 2030 & GTR 2030 & GTI 2030 \\
\hline Rice & - & - & + \\
Wheat & - & - & + \\
Other grain products & - & - & + \\
Vegetable and fruits & - & - & + \\
Oil seeds & - & - & + \\
Bovine cattle, sheep, and goats, horses & - & - & + \\
Other animal products & - & + & - \\
Fishery products & + & - & + \\
Bovine meat products & - & - & + \\
Other meat products & - & - & + \\
Vegetable oils and fats & - & & \\
\hline
\end{tabular}


Table 11 Private consumption and sectoral price change in CAM and CKM 2030, compared with BAU 2030. Sources: results from the study

\begin{tabular}{|c|c|c|c|c|}
\hline \multirow[t]{2}{*}{ Sectors } & \multicolumn{2}{|c|}{ Private consumption } & \multicolumn{2}{|l|}{ Food price } \\
\hline & CAM 2030 & CKM 2030 & CAM 2030 & CKM 2030 \\
\hline Rice & + & - & - & + \\
\hline Wheat & + & - & - & + \\
\hline Other grain products & + & - & - & + \\
\hline Vegetable and fruits & + & - & - & + \\
\hline Oil seeds & + & - & - & + \\
\hline Bovine cattle, sheep, and goats, horses & + & - & - & + \\
\hline Other animal products & - & - & - & + \\
\hline Fishery products & + & - & - & + \\
\hline Bovine meat products & + & - & - & + \\
\hline Other meat products & - & - & - & + \\
\hline Vegetable oils and fats & + & - & - & + \\
\hline
\end{tabular}

compared with the BAU 2030 scenario. The output of oilseeds and vegetable oils and fats is expected to be higher than it is in the BAU 2030 scenario as well by 50.2 and $49.3 \%$, respectively. Overall, a mandated rice growth rate policy has had significant and positive impacts on major agricultural products (Table 12). The wheat mandated growth rate (MWG) experiment shows similar results, but at a different level of magnitude. Under the MWG 2030 scenario, the wheat sector is the most affected sector as expected. Wheat output is likely to increase by $20.6 \%$ compared with the BAU 2030 scenario. For the rice and other grains sectors, their outputs do not show large improvement, as they are only 1.7 and 1\% larger, respectively (Table 12). Compared with the MRG 2030 scenario, the output growth effects of these sectors are less significant in the MWG 2030 scenario. For the beef animal sector, other animal sector, beef meat sector, and other meat sector increases were expected in the order of 1.9, 3.2, 2.4, and 5.3\% in the MWG 2030 scenario, respectively, compared with their growth rates in the BAU 2030 scenario. The rest of the agricultural sectors were expected to have positive yield changes in both scenarios, but the changes were found to be of a smaller magnitude in the MWG scenario.

The self-sufficiency rates that change under the MRG and MWG scenarios are presented in Table 13. These results suggest that the mandated rice and wheat growth rate policies are expected to improve the target grain (rice or wheat) commodity self-sufficiency rates significantly, while little effects will be felt on the remaining grain product self-sufficiency rates. For instance, if the government sets the rice mandated growth rate at $2.05 \%$ per annum, the rice self-sufficiency rate is expected to improve from $95.05 \%$ to over $100 \%$ for 2030 and from 82.25 to $106.16 \%$ for 2050 . Wheat and other grain selfsufficiency rates are expected to increase by 0.71 and $0.32 \%$ for 2030 and 1.25 and $0.44 \%$ for 2050, respectively. Therefore, wheat's self-sufficiency rate continues to be lower than the government's target for both 2030 and 2050 in the MRG scenario.

If the government sets a mandated growth rate for the wheat sector, the self-sufficiency rate for wheat is likely to improve by $29.18 \%$ for 2030 and $37.99 \%$ for 2050 , which are above the government's wheat security target. However, the opposite results are shown for the rest of the grain sectors. The self-sufficiency rates for rice and other grains 
Table 12 Sectoral output growth rate change (\%) in MRG and WRG 2030, compared with BAU 2030. Sources: results from the study

\begin{tabular}{lcc}
\hline Sectors & MRG 2030 & WRG 2030 \\
\hline Rice & 20.6 & 1.7 \\
Wheat & 35.1 & 20.6 \\
Other grain products & 21.5 & 1.0 \\
Vegetable and fruits & 19.3 & 1.0 \\
Oil seeds & 50.2 & 1.2 \\
Bovine cattle, sheep, and goats, horses & 17.4 & 1.0 \\
Other animal products & 34.3 & 3.2 \\
Raw milk & 34.4 & 3.0 \\
Fishery products & 3.2 & 0.2 \\
Bovine meat products & 26.7 & 1.4 \\
Other meat products & 48.3 & 5.3 \\
Vegetable oils and fats & 49.3 & 1.4 \\
\hline
\end{tabular}

are likely to decrease by 1.01 and $1.92 \%$ for 2030 , respectively. For 2050 , the self-sufficiency rates for both rice and other grain products are expected to decline by $1.03 \%$ in the MWG 2050 scenario.

\subsubsection{Import and export}

The crop with a government mandated growth rate policy is likely to record an impressive increase in export volume and a considerable decrease in the volume of imports. For the MRG 2030 scenario, compared with the BAU 2030 scenario, volume for both rice and wheat are expected to decline in terms of imports and expand in terms of exports, while for other grain products, both exports and imports are likely to increase. However, the export growth rate (39.54\%) is expected to be higher than the import growth rate (2.12\%). The other agricultural products are expected to exhibit similar effects as rice and wheat, except for oilseeds. Imports of oilseeds are likely to increase by $27.3 \%$, and exports are expected to increase by $8.2 \%$. Thus, the import growth rate is much higher than its export growth rate. The results are more complex for the MWG 2030 scenario as in this case there is likely to be a decrease in wheat imports and an increase in wheat exports while the opposite results show up in the rice sector. It might be because more inputs are shifted to the wheat sector from the rice sector due to the mandated wheat growth rate policy. For the other grains sector, even though both imports and exports are likely to increase, the import growth rate $(2.09 \%)$ is higher than its export growth rate $(1.27 \%)$. For all the meat and livestock sectors, imports are expected to increase while exports are expected to decrease in the MWG 2030 scenario (Table 14).

Table 13 Self-sufficiency rate for grain in 2030 and 2050, compared with BAU. Sources: results from the study

\begin{tabular}{lcccc}
\hline Sectors & \multicolumn{2}{l}{ MRG } & & \multicolumn{2}{l}{ WRG } \\
\cline { 2 - 3 } & $\mathbf{2 0 3 0 ( \% )}$ & $\mathbf{2 0 5 0 ( \% )}$ & $\mathbf{2 0 3 0 ( \% )}$ & $\mathbf{2 0 5 0 ( \% )}$ \\
\hline Rice & 23.24 & 23.91 & -0.01 & -0.03 \\
Wheat & 0.71 & 1.25 & 29.18 & 37.99 \\
Other grain & 0.32 & 0.44 & -0.02 & -0.03 \\
\hline
\end{tabular}


Table 14 Export and import growth change in MGR and MWR, compared with BAU 2030. Sources: results from the study

\begin{tabular}{|c|c|c|c|c|}
\hline \multirow[t]{2}{*}{ Sectors } & \multicolumn{2}{|c|}{ MRG 2030} & \multicolumn{2}{|c|}{ MWG 2030} \\
\hline & Import & Export & Import & Export \\
\hline Rice & - & + & + & - \\
\hline Wheat & - & + & - & + \\
\hline Other grain products & + & + & + & + \\
\hline Vegetable and fruits & - & + & + & + \\
\hline Oil seeds & + & + & + & - \\
\hline Bovine cattle, sheep, and goats, horses & - & + & - & + \\
\hline Other animal products & - & + & - & + \\
\hline Raw milk & - & + & - & + \\
\hline Fishery products & + & - & + & - \\
\hline Bovine meat products & - & + & - & + \\
\hline Other meat products & - & + & - & + \\
\hline Vegetable oils and fats & - & + & - & + \\
\hline
\end{tabular}

\subsubsection{Private consumption and food price}

Table 15 presents private consumption levels and food price changes for different grain mandated growth scenarios (MWG and MRG) 2030 and the BAU 2030 scenario. Generally speaking, the majority of agricultural products and food commodities have consumption volumes that are expected to increase as a result of the policy interventions. Chinese consumers are predicted to consume more food under both the MRG 2030 and MWG 2030 scenarios, but the consumption of the majority of agricultural goods is increased more significantly under the rice mandated growth scenario.

In the MRG 2030 scenario, rice and wheat consumption is expected to increase 84.48 and $20.5 \%$, respectively. Other grain product consumption rates will increase by $28.63 \%$. The estimation of the nation's overall demand for meat, animal products, oilseeds and vegetable oil and fat commodities would be higher than they proved to be

Table 15 Private consumption and sectoral price change in MRG and MWG 2030, compared with BAU 2030. Sources: results from the study

\begin{tabular}{|c|c|c|c|c|}
\hline \multirow[t]{2}{*}{ Sectors } & \multicolumn{2}{|c|}{ Private consumption } & \multicolumn{2}{|l|}{ Food price } \\
\hline & MRG 2030 & MWG 2030 & MRG 2030 & MWG 2030 \\
\hline Rice & + & + & - & - \\
\hline Wheat & + & + & - & - \\
\hline Other grain products & + & + & - & - \\
\hline Vegetable and fruits & + & + & - & - \\
\hline Oil seeds & + & + & - & - \\
\hline Bovine cattle, sheep, and goats, horses & + & + & - & - \\
\hline Other animal products & + & + & - & - \\
\hline Fishery products & - & - & + & + \\
\hline Bovine meat products & + & + & - & - \\
\hline Other meat products & + & + & - & - \\
\hline Vegetable oils and fats & + & + & - & - \\
\hline
\end{tabular}


under the BAU 2050 scenario by $14-37 \%$. For instance, private consumption for vegetable and fruits is expected to increase by 16\% in the MRG 2030 scenario and by $1.11 \%$ in the WMG 2030 scenario. The consumption of oilseeds is likely to increase by $21 \%$ in the RMG 2030 scenario and by $0.67 \%$ in the MWG scenario. For beef animals and beef meat sectors, the levels of private consumption are expected to increase by 29 and $32 \%$, respectively, while private consumption levels are likely to increase by 2.6 and $3.7 \%$, respectively, in the MWG 2030 scenario.

Both MRG and MWG scenarios are expected to decrease overall food prices, except for fishery products. Price effects of the MRG scenario are larger than similar effects for the MWG scenario. The study provides estimates of prices that are expected to decline by 16,21 , and around $30 \%$ for vegetables, oilseeds and livestock products, respectively, in the MRG scenario. The MWG scenario is expected to have a moderate influence on food prices with the prices of rice and other grain products are expected to decline by 0.65 and $0.96 \%$, respectively. The price for oilseeds and vegetable oils and fats are expected to increase by 1.05 and $1.54 \%$, respectively. For meat and livestock sectors, beef cattle, sheep, goats, and horses (5.2\%) and the other animal sector $(9.27 \%)$ are expected to experience a larger price reduction than the beef meat (1.64\%) and other meat sectors (8.1\%).

The consumption volume and price changes for fishery products appear to respond in the opposite direction to the other agricultural sectors. In both the MRG and MWG scenarios, private consumption of fishery products is expected to decrease, while the prices for fishery products are predicted to increase by 2030, compared with the BAU 2030 scenario.

\subsection{Welfare implication for all scenarios}

In the GTAP model, each region's representative agent aims to maximize the level of utility. When a policy is changed, the agent calculates a change in income level which affects the scale of savings and consumption for each commodity in such a way that the marginal utility of consumption is the same across all commodities. In this case, agents use prices to clear the market in the decision-making process. In free trade experiments, the welfare level of agents in one region would improve, while that of a trading partner would likely decrease. The welfare changes for China under different scenarios are presented in Table 16.

Table 16 China's welfare implications of difference scenarios, compared with BAU. Sources: results from the study

Welfare effects

\begin{tabular}{lc}
\hline MTR & - \\
GTR & - \\
GTI & + \\
CAM & + \\
CKM & + \\
MRG & + \\
MWG & + \\
\hline
\end{tabular}


In the cases of GTR and GTI scenarios, China's welfare is not expected to experience significant changes. China appears to gain slightly if the government increases grain tariff. If grain tariff is removed, then the opposite result is expected to occur. For two free trade meat agreement scenarios, compared against welfare in the same period for BAU, China is expected to experience a welfare loss in 2030 if it removes the meat import tariff for Australia and New Zealand. On the other hand, Australia and New Zealand's welfare are expected to improve by 2030, compared to the same period under the BAU scenario. It is worth mentioning that this free trade meat agreement is expected to generate positive welfare effects for China in 2050. The CKM scenario welfare change indicates that China is expected to gain throughout the projection period, in response to Korea removing all meat import tariffs for China's livestock and meat products. Results for this scenario showed that this free trade meat agreement results in a win-win situation for both China and Korea. As for the mandatory growth rates of rice and wheat, China appears likely to experience considerable welfare gains.

Under the current agricultural productivity level, the current quantity of arable land is not enough to secure the government's target for grain self-sufficiency (95\%) in 2030. The "Red Line" policy for arable land is not enough to meet government's grain security target in 2030; moreover, land resources for the purpose of reclamation is limited. To safeguard national food security, given this situation, government policy interventions appear unavoidable.

According to projected results from this study, a meat import tariff reduction scenario is likely to improve grain self-sufficiency rates along with domestic food consumption which could possibly culminate in a decrease in food prices. Even though China's welfare is expected to decrease under the MTR scenario, meat tariff reduction still helps China's government to achieve its grain security target and enhance domestic food consumption. Lowering food prices in the MTR 2030 scenario lead to food being more accessible to the poorer sections. Grain tariff adjustments are expected to have little effect on China's welfare. Grain tariff reductions are helpful in improving food accessibility, but they are not helpful in improving grain's self-sufficiency rates. On the other hand, an increasing grain tariff policy is expected to meet the government's grain self-sufficiency targets, but the domestic food consumption will decrease and food prices will subsequently rise. Therefore, if the government aims to safeguard grain self-sufficiency by increasing grain import tariffs, it appears harmful to the goal of e national food security. Unlike the free trade meat agreement with Korea (CKM), a reduced meat import tariff for Australia is expected to bring more benefits to China's food security. China is expected to increase the majority of its agricultural commodities' output levels, improve grain self-sufficiency rates, gain welfare, decrease food prices and increase private food consumption levels with the CAM scenario. In addition, the CAM scenario is helpful for poverty alleviation in China. Conversely, the China-Korea free trade meat agreement is not expected to benefit China's food security, even though China's meat exports will be stimulated. Mandated grain growth rates could be expected to have significant positive impact on important food security indicators. In addition, the policies appear to be beneficial for national welfare for both MRG and MWG scenarios. 


\section{Conclusion and policy}

It ensures that food security is a focus for all the countries in the world and a major development strategy for China to promote economic development, maintain social stability, and achieve a national self-sufficiency rate for basic food ingredients.

China's food production capacity is constrained by the limited availability of land and water resources (Zhou 2010), and its agricultural productivity is $46 \%$ of the average world productivity value. However, rapid income growth and a large population base have led to a substantial domestic demand for agricultural commodities. As a result, China's agricultural trade deficit has been rising for some years now. This is particularly true for grain products, as China became a net importer of grain in 2010, and this trend is expected to continue for the foreseeable future. Thus it puts pressure on China's food security target of $95 \%$ for rice and wheat self-sufficiency rates. Given China's large and growing population, the attainment of food security appears to be a national and global issue. In this backdrop, the current study objective is to investigate China's food security situation in 2030 and investigate the impacts of alternative policies on food security.

The results from this study suggest that China is expected to achieve a grain self-sufficiency level of a little above $90 \%$ by the year 2030, but less than $90 \%$ by the year 2050 . Without any policy intervention in the Business as Usual (BAU) scenario the self-sufficiency rate for rice is expected to be $82.25 \%$ and for wheat the rate will be $84.97 \%$ by 2050. The total value of agricultural imports and exports are expected to increase substantially. In addition, the current "Red Line" arable land protection policy (1800 million $\mathrm{mu}$ ) is determined to be insufficient to allow for the production of enough grain by the year 2030 to meet the desired 95\% self-sufficiency rate. Moreover, it is not enough to meet 90\% (2727.495 million $\mathrm{mu}$ ) and 95\% (2879.022 million $\mathrm{mu}$ ) self-sufficiency rates by the year 2050. Study results indicate that arable land should be strictly protected for food production against pressure from industrialization and urbanization. However, it is only part of the food security solution. Therefore, policy interventions are crucial to ensure that China's food security targets are met.

Agricultural and trade policy impacts on the Chinese economy were estimated for this study. The MTR (meat tariff reduction) seems to have a greater impact on China's food security than the GTR (grain tariff reduction). With respect to the MTR, outputs of rice and wheat are expected to increase substantially, thus the grain self-sufficiency rates are expected to improve by 2030 and to be above $90 \%$ in 2050 . The GTR scenario produces few positive effects on grain self-sufficiency rates and agricultural trade values, while there is a marginal negative impact on society welfare. Compared with the GTR, a GTI (grain tariff increase) is expected to raise the grain self-sufficiency rates considerably for both 2030 and 2050. In 2030, with the GTI policy, the rice and wheat self-sufficiency rates are expected to increase to 98.8 and $97.2 \%$ in 2030, respectively. All the grain product self-sufficiency rates are estimated to be over $95 \%$ in 2050 . However, national food prices are expected to increase and private food consumption is expected to decline. The poor food buyers will be mostly affected, since the food is unaffordable, possibly resulting in an increase in the incidence of malnourishment. In this study, we have captured the impact of two recent free trade agreements signed by China. The CAM (China-Australia meat free trade agreement) results in greater positive effects on China's food security than the CKM (China-Korea meat free trade agreement). CAM results indicate an 
increase in private consumption and a decrease in food prices, while the CKM appears to present the opposite results. In the case of a mandated rate of growth for rice (MRG) and a mandated rate of growth for wheat (MWG), it appears that these are effective in encouraging an improvement in the self-sufficiency rates of the grain target policy. These policies also reveal a substantial increment in output levels. Wages of unskilled labor and national welfare under both policies are likely to increase. These impacts will also help to reduce food prices and stimulate food consumption. Factor returns to unskilled labor are also expected to increase considerably.

\subsection{Policy recommendations}

The findings of this study indicates that to attain China's grain security target in 2030 and 2050, the country must preserve and even increase its grain production areas through restrictions on the conversion of arable land for other purposes. This is because the simple preservation of existing arable land, through policies such as the "Red Line" policy, seems incapable of maintaining grain self-sufficiency rates at the target level by 2030 and 2050. The government should also encourage the reclamation of abandoned residential areas so that the land can once again be used for food production. Rural governments should strictly define and enforce land use rights. Well-defined land use rights will result in a sound land market, as well as promoting a rational allocation of land resources.

Since China's agricultural production and thus supply are subject to limited natural resources, it is widely accepted that imports of foods from the international market will be unavoidable. Since China has joined the WTO, China's food market has become more integrated into the world market. Since grain products are all exempted in all free trade agreements with China, it has been argued that China should decrease its grain import tariff to better meet domestic demand. The results of this study indicate that grain tariff adjustments are in fact not a good policy option. Feed grains compete for resources with food grains; therefore, a free trade in meat policy is likely to release more available production resources into the food grain sectors than other policies. Instead of reducing grain tariffs, governments should focus on this meat trade policy as a meat tariff reduction is more effective in enhancing China's food security than tariff adjustments for grain. Australia and New Zealand are expected to become important meat and livestock suppliers to China and can be preempted by the China-Australia free trade agreement that is under negotiation.

\section{Authors' contributions}

This study is based on a Master thesis submitted by Jingyuan Zhang, 2015. However, the corresponding author has recalculated the entire exercise using recent database of GTAP. The corresponding author has done the modeling exercise, designing the research, and drafting the manuscript. Aside from this, all authors have contributed in revising the manuscript. They have also given final approval of the version to be published. All authors read and approved the final manuscript.

Author details

${ }^{1}$ Department of Natural Resource Sciences, Agricultural Economics Program, McGill University, Macdonald Campus, 21,111 Lakeshore Road, Ste Anne de Bellevue, Montreal, QC H9X3V9, Canada. ${ }^{2}$ Gokhale Institute of Politics and Economics, Pune 411004, India. ${ }^{3}$ Academy of Mathematics and Systems Science, CAS, Rm. 409, Siyuan Building, 55 Zhongguancun Dong Lu, Haidian District, Beijing 100190, People's Republic of China.

\section{Acknowledgements}

Not applicable.

Competing interests

The authors declare that they have no competing interests. 
Availability of data and materials

The dataset supporting the conclusions of this article are available in and bought from the GTAP database version 9 .

\section{Consent for publication \\ Not applicable.}

\section{Ethics approval and consent to participate}

Not applicable.

Funding

Not applicable.

\section{Publisher's Note}

Springer Nature remains neutral with regard to jurisdictional claims in published maps and institutional affiliations.

Received: 15 October 2017 Accepted: 4 December 2017

Published online: 05 January 2018

\section{References}

Alexandratos N, Bruinsma J (2012) World Agriculture towards 2030/2050: the 2012 revision. In: ESA working paper no. 12-03, Global Perspective Studies Team, Agricultural Department Economics Division, Food and Agricultural Organization of United Nations, FAO, Rome

Anderson K, Strutt A (2014) Food security policy options for China: lessons from other countries. Food Policy 49:50-58 Beddington JR, Asaduzzaman M, Clark ME, Bremauntz AF, Guillou MD, Jahn MM, Lin E, Mamo T, Negra C, Nobre CA (2012) The role for scientists in tackling food insecurity and climate change. Agric Food Secur 1(1):1-9

Brown LR (1994) World watch. World Watch Inst 7(5):10-19

Chen Y (2004) China food demand and supply analysis and projection. China Agricultural Press, Beijing

Chen J (2007) Rapid urbanization in China: a real challenge to soil protection and food security. CATENA 69(1):1-15

Chen G (2012) Current China's grain supply and demand, and medium-run trends. http://www.cngrain.com/Publish/ news/201204/521567.shtml. Accessed 27 June 2014

Chen YLJ, Ma G, Jing Z (2010) Future trend forecast for food supply and demand. J Shanxi Univ (Philos Soc Sci) 33(5):10-19

Diao X, Fan S, Zhang X (2003) Regional impact of WTO on China's agricultural sector. China Agriculture Press, Beijing

Fan M, Zheng Y, Qi S, Chen J (2008) China's scheduled trade liberalization and the impact on food security. Agric Econ Probl S(1):3-14

FAO (2009) Declaration of the world food summit on food security. Food and Agriculture Organization of the United Nations, Rome. http://www.fao.org/fileadmin/templates/est/meetings/wto_comm/Trade_policy_brief_China_final. pdf. Accessed 16 Oct 2014

FAO, WFP and IFAD (2012) The state of food insecurity in the world 2012. Economic growth is necessary but not sufficient to accelerate reduction of hunger and malnutrition. FAO, Rome. http://www.fao.org/docrep/016/i3027e/i3027e00. htm. Accessed 6 Oct 2014

Fouré J, Bénassy-Quéré A, Fontagné L (2010) The world economy in 2050: a tentative picture. CEPII Working Paper, No. 27

Hertel TW (1997) Structure of GTAP. Global trade analysis: modeling and applications. Cambridge University Press, Cambridge, pp 13-73

Huang P, Jiabao Y (1997) 2000-2030 China grain demand and supply balance and related policies analysis. Agric Econ Issus 2:9-14

Huang J, Yang J (2006) China's economic growth and its food security. Chin Acad Sci J 2006(1):61-82

Huang D, Li X, Cai S (2010a) Impact of agricultural subsidies on Chinese food security based on China agricultural CGE model. Chin Agric Sci Bull 26(24):429-435

Huang D, Li X, Cai S, An Y (2010b) Impact of technology policies on Chinese food security based on China agricultural CGE model. Chin Agric Sci Bull 24(5):32-42

Huang J, Yang J, Msangi S, Rozelle S, Weersink A (2012) Biofuels and the poor: global impact pathways of biofuels on agricultural markets. Food Policy 37(4):439-451

Kang X (1998) The food supply strategy in the global Village Era-China's grain international trade and grian security. Tianjin People's Publishing House, Tianjin

Li S, He J (2010) Prospects for China's economic growth prospects in 2030: based on DRCCGE model. http://www.esri. go.jp/jp/prj/int_prj/2010/prj2010_03_02.pdf. Accessed 14 May 2014

Liao Y (2010) China's food security. Chin Econ 43(3):103-108

Liu M (2013) The research on the effects of agricultural machinlization, Rural Land Administration Reformation on Grain Output. Ph.D. dissertation. Henan University, Henan

Ludena CE, Hertel TW, Preckel PV, Foster K, Nin A (2007) Productivity growth and convergence in crop, ruminant, and nonruminant production: measurement and forecasts. Agric Econ 37(1):1-17

Mold A, Frooki M, Annalisa P, Giovanni V (2014) Achieving greater food security through south-south trade? A CGE analysis of the potential impact of food trade liberalisation. https://www.gtap.agecon.purdue.edu/resources/download/7074.pdf. Accessed 23 Oct 2014

Mukhopadhyay K, Thomassin PJ (2009) Economic and environmental impact of free trade in East and South East Asia. Springer, Berlin 
Narayanan GB, Aguiar A, McDougall R (2012) Global trade, assistance, and production: the GTAP 8 data base. http://www. gtap.agecon.purdue.edu/databases/v8/v8_doco.asp. Accessed 25 Aug

National Bureau of Statistics of China (NBSC) (2010) China statistical yearbook (various issues). China Statistical Press, Beijing

Qian W (2014) China to "maintain self-sufficiency in food production. China daily (April 21, 2014). http://www.chinadaily. com.cn/china/2014-04/21/content_17450136.htm. Accessed 14 June 2014

Rada NE, Rosen S, Beckman JF (2013). Evaluating agricultural productivity's impact on food security. In: Paper presented at the international agricultural trade research consortium's (IATRC's) 2013 symposium: productivity and its impacts on global trade meeting, Seville, Spain, June 2-4, 2013. http://purl.umn.edu/152265

Ren X (2012) Effects of climate change on China's grain production and trade policy. Ph.D. dissertation. Chinese Academy of Agricultural Sciences, Beijing

Rosegrant MW, Msangi S, Ringler C, Sulser TB, Zhu T, Cline SA (2008) International Model for policy analysis of agricultural commodities and trade (IMPACT): model description. International Food Policy Research Institute, Washington

Strutt A, Nelgen S (2013) Food security scenarios for the Asia Pacific: inter-sectoral and inter-economy perspectives. In: Paper presented at the 2013 meeting food security goals with good policy regional dialogue meeting. June 26June 27, 2013

The CCCPC and The State Council (2014) The 2014 no. 1 document of the CCCPC and the State Council. USDA Foreign Agricultural Service, Beijing. http://gain.fas.usda.gov/RecentGAINPublications/The 2014 No. 1 Document of the CCCPC and the State Council_Beijing_China-Peoples Republic of_3-5-2014.pdf

Wang Z (2012) How to change China's agricultural productivity fall behind U.S. 100 years. China's Econ Netw (May 15, 2012) (In Chinese). http://views.ce.cn/view/ent/201205/15/t20120515_23322085.shtml. Accessed 14 Oct 2014

World Bank (2013) China 2030: building a modern, harmonious, and creative society. The World Bank Development Research Center of the State Council, the People's Republic of China

World Bank (2014a) Population estimates and projections. http://data.worldbank.org/data-catalog/population-projection-tables. Accessed 10 Oct 2014

World Bank (2014b) GDP ranking. http://data.worldbank.org/data-catalog/GDP-ranking-table. Accessed 9 Oct 2014

World Bank (2014c) Arable land (hectares per person). http://data.worldbank.org/indicator/AG.LND.ARBL.HA.PC/ countries?display=default. Accessed 9 Oct 2014

World Bank (2016) World Development Report, Digital Dividends. World Development Report 2016,Washington DC. http://documents.worldbank.org/curated/en/896971468194972881/pdf/102725-PUB-Replacement-PUBLIC.pdf. Accessed 9 Jan 2017

Yu W, Bandara JS (2014) India's grain security policy in the era of high food prices: a computable general equilibrium analysis. In: Paper presented at the EAAE 2014 Congress 'Agri-Food and Rural Innovations for Healthier Societies', Ljubljana, Slovenia, August 26-August 29, 2014. http://ageconsearch.umn.edu/bitstream/182694/2/YuIndia\%E2\%80\%99s_grain_security_policy_in_the_era_of_high_food_prices-616_a.pdf

Zhang Z (2009) Research on the impact of biofuels on food security. Ph.D. dissertation. Zhejiang University of Technology, Zhejiang

Zhou Z (2010) Achieving food security in China: past three decades and beyond. China Agric Econ Rev 2(3):251-275

\section{Submit your manuscript to a SpringerOpen ${ }^{\circ}$ journal and benefit from:}

- Convenient online submission

- Rigorous peer review

- Open access: articles freely available online

- High visibility within the field

- Retaining the copyright to your article

Submit your next manuscript at $\boldsymbol{\nabla}$ springeropen.com 